\title{
Assessment of the Influence of the Process of Underground Uranium Leaching on Soil and Groundwater
}

\author{
Allaberganova G.M. ${ }^{{ }^{*}}$, Turobzhonov S. $^{2}$, Muzafarov A.M. ${ }^{3}$, Kholov D.M. ${ }^{4}$ \\ ${ }^{1}$ Navoi State Mining Institute \\ ${ }^{2}$ Tashkent State Technical University \\ ${ }^{3}$ Central Scientific Research Laboratory of NMMC, \\ ${ }^{4}$ Navoi State Pedagogical Institute Navoi city, 210100, Uzbekistan University of Mines and Technology, P. O. \\ Box 237, Tarkwa
}

*Corresponding Author: Allaberganova G.M, Navoi State Mining Institute

\begin{abstract}
The paper presents the results of evaluating the influence of the process of underground leaching of uranium on the state of soil and groundwater. The value of the equivalent dose rate of gamma radiation (EDR) was determined, in laboratory conditions the concentrations of rock-forming chemical elements were determined by the $X$-ray fluorescence method, the effective specific activity of alpha radiation - $A_{\text {eff, }}$ he specific activity of radionuclides in soil samples were determined as well as dry residue, pH value, anions $\mathrm{Cl}, \mathrm{NO}^{2-}, \mathrm{NO}^{3-}, \mathrm{CO}_{3}{ }^{2-}, \mathrm{HCO}_{3}{ }^{-}, \mathrm{SO}_{4}{ }^{2-}$, and their sum, cations $-\mathrm{Ca}^{+}, \mathrm{Mg}^{+}, \mathrm{Na}^{+}, \mathrm{K}^{+}, \mathrm{Fe}^{3+}, \mathrm{NH}_{4}$ and their sum and concentration of metals $-\mathrm{Mn}, \mathrm{Pb}, \mathrm{Cu}, \mathrm{Zn}, \mathrm{Co}, \mathrm{Cr}, \mathrm{Ni}$ in groundwater samples.
\end{abstract}

Keywords: underground uranium leaching, soil condition, groundwater state, X-ray fluorescence analysis method, chemical element, effective specific activity of alpha radiation, specific activity of radionuclides, soil samples, underground samples, dry residue, $p H$ values, anions and their sum, cations and their sum, metal concentration.

\section{INTRODUCTION}

Urgency. During mining of uranium deposits - by the method of underground leaching of uranium, the soil and groundwater are contaminated to a varying degree, by the radionuclides of the uranium decay chain $-\mathrm{U}^{238}, \mathrm{U}^{234}, \mathrm{Th}^{230}, \mathrm{Ra}^{226}, \mathrm{Rn}^{222}, \mathrm{Bi}^{214}, \mathrm{~Pb} 214, \mathrm{Po}^{210}$, etc. The reason for this phenomenon is a violation of the technological regulations for pumping, injection, leakage, condition of pipelines, improper organization of transportation of productive solutions, etc.Soil contamination and groundwater by radioactive elements negatively affect their radiation, chemical, biological, erosion, aesthetic characteristics, will lead to the death or degradation of the vegetation cover, loss of fertility, a change in the structure of the earth's surface and a deterioration in the quality of groundwater.

In addition, for such facilities, the limit of permissible concentration of radionuclides is established and their value is regulated by normative International and Republican documents [1].Determination of values and their values in soils and groundwaters is an urgent task of analytical chemistry, applied nuclear physics and radioecology [2-8].

The purpose of this study was to determine the values of radioactive contaminants in soils and groundwater, their distribution in the acid method of underground leaching of uranium.To achieve this goal, samples taken from soil and groundwater were studied, concentrations of radioactive elements were determined, and their distribution was studied.

\section{EXPERIMENTAL MeThodS AND TECHNiQues}

Technique and experimental procedure. on the basis of certain values of the equivalent dose rate of gamma radiation (EDR) on the DKS-96 device, contaminated sites were found in the areas of underground leaching of uranium, in laboratory soil samples from these places under laboratory conditions were determined by the X-ray fluorescence method of the concentration of rock-forming chemical elements on the device EDX-7000 (SHMADZU, Japan), determined the value of the 
effective specific activity of alpha radiation - $\mathrm{A}_{\text {eff }}$ on the BIA device and the specific activity of radionuclides - $\mathrm{Ra}^{226}, \mathrm{Th}^{232}$ and $\mathrm{K}^{40}$ gamma - spectrometric method on the device "Gamma progress".

The following are determined in groundwater - dry residue, $\mathrm{pH}$ values, anions - $\mathrm{Cl}^{-}, \mathrm{NO}^{2-}, \mathrm{NO}^{3-}, \mathrm{CO}_{3}{ }^{2-}$ $, \mathrm{HCO}_{3}{ }^{-}, \mathrm{SO}_{4}^{2-}$, and their sum, cations $-\mathrm{Ca}^{+}, \mathrm{Mg}^{+}, \mathrm{Na}^{+}, \mathrm{K}^{+}, \mathrm{Fe}^{3+}, \mathrm{NH}_{4}$ and their sum - by the photocolorimetric method and metal concentrations - $\mathrm{Mn}, \mathrm{Pb}, \mathrm{Cu}, \mathrm{Zn}, \mathrm{Co}, \mathrm{Cr}, \mathrm{Ni}$ - by the atomic absorption method.

\section{RESULTS AND DISCUSSION}

Assessment of groundwater conditions during underground leaching of uranium. During underground leaching of uranium, groundwater is contaminated by various components contained in the working solution, as well as by substances formed as a result of the interaction of the leaching solution with ore-bearing rock. During sulfuric acid leaching, in addition to uranium, from the rock to underground waters in quantities exceeding the maximum permissible concentrations (MPC) for ground water, various chemical elements pass ( $\mathrm{Fe}, \mathrm{Al}, \mathrm{Ca}, \mathrm{Cu}, \mathrm{Mo}$, etc.). The total salinity of groundwater in such a process can reach up to $30 \mathrm{~g} / 1$ (and the total salinity for industrial water is established - $1 \mathrm{~g} / \mathrm{l})$. The obtained technological uranium-containing solutions also contain radionuclides - $\mathrm{U}^{234}, \mathrm{Th}^{230}, \mathrm{Ra}^{226}, \mathrm{Rn}^{222}, \mathrm{Bi}^{214}, \mathrm{~Pb}^{214}, \mathrm{Po}^{210}$, etc.

Studies of the behavior of various radionuclides in groundwater show that when sulfuric acid underground leaching of uranium is observed pollution of these objects with different amounts of radionuclides.

Table 1 compares the composition of groundwater and technological solutions in the sulfuric acid method of leaching of uranium.

For the above samples in Table 1, the $\mathrm{pH}$ value varies between 7.2-8.5 for groundwater, and for solutions of underground leaching of uranium 1.5-5.2, the dry residue varies between (1840-28046) $\mathrm{mg} / \mathrm{l}$ for groundwater, and for solutions of underground leaching (14964-70932) $\mathrm{mg} / \mathrm{l}$, the hardness varies in the range $(10.2-12.7) \mathrm{mg} / 1$ for groundwater, and for solutions of underground leaching (53.2 - 74.6) $\mathrm{mg} / 1$.

Table1. Comparison of the composition of natural waters and technological solutions in the sulfuric acid method of leaching of uranium

\begin{tabular}{|c|c|c|c|c|c|c|c|c|c|c|c|c|c|}
\hline \multirow{2}{*}{$\begin{array}{c}\text { No. of } \\
\text { sampl } \\
\text { es }\end{array}$} & \multicolumn{6}{|c|}{ C A T I O N S mg/dm } & \multicolumn{7}{|c|}{ A N I O N S mg/dm 3} \\
\hline & $\mathrm{Ca}^{2+}$ & $\underset{2+}{\mathbf{M g}}$ & $\mathrm{Na}^{+}+\mathrm{K}^{+}$ & $\underset{3+}{\mathbf{F e}}$ & $\begin{array}{c}\mathrm{NH}_{+}^{+} \\
4^{+}\end{array}$ & $\sum$ & $\mathrm{CO}_{2-}$ & $\begin{array}{l}\mathrm{HC} \\
\mathrm{O}_{3}^{-}\end{array}$ & $\mathrm{SO}_{4}{ }^{2}$ & $\mathrm{Cl}^{-}$ & $\begin{array}{c}\text { NO } \\
2\end{array}$ & $\begin{array}{c}\text { NO } \\
3\end{array}$ & $\sum$ \\
\hline \multicolumn{14}{|c|}{ groundwater samples } \\
\hline 1 & $\begin{array}{c}122, \\
24\end{array}$ & $\begin{array}{c}52,2 \\
9\end{array}$ & $\begin{array}{c}244,60+7 \\
, 30\end{array}$ & $\begin{array}{c}0,2 \\
5\end{array}$ & $\begin{array}{c}0,6 \\
7 \\
\end{array}$ & $\begin{array}{c}427, \\
35\end{array}$ & 7,50 & $\begin{array}{c}222 \\
72\end{array}$ & $\begin{array}{c}511, \\
62\end{array}$ & $\begin{array}{c}237, \\
52\end{array}$ & $\begin{array}{l}<0, \\
02\end{array}$ & 1,31 & $\begin{array}{c}980, \\
67\end{array}$ \\
\hline 2 & $\begin{array}{c}122, \\
24\end{array}$ & $\begin{array}{c}54,7 \\
2\end{array}$ & $\begin{array}{c}243,20+7 \\
, 30\end{array}$ & $\begin{array}{c}0,2 \\
5\end{array}$ & $\begin{array}{c}1,2 \\
4\end{array}$ & $\begin{array}{c}428, \\
95\end{array}$ & 7,50 & $\begin{array}{c}228 \\
82\end{array}$ & $\begin{array}{c}505, \\
85\end{array}$ & $\begin{array}{c}244, \\
61\end{array}$ & $\begin{array}{l}<0, \\
02\end{array}$ & 0,60 & $\begin{array}{c}987, \\
38\end{array}$ \\
\hline 3 & $\begin{array}{c}122, \\
24\end{array}$ & $\begin{array}{c}71,7 \\
5 \\
\end{array}$ & $\begin{array}{c}169,00+7 \\
, 70\end{array}$ & $\begin{array}{c}0,2 \\
7\end{array}$ & $\begin{array}{c}1,3 \\
7 \\
\end{array}$ & $\begin{array}{c}372, \\
33\end{array}$ & 4,50 & $\begin{array}{c}228 \\
83\end{array}$ & $\begin{array}{c}510, \\
38\end{array}$ & $\begin{array}{c}173, \\
71 \\
\end{array}$ & $\begin{array}{l}<0, \\
02\end{array}$ & $\begin{array}{c}13,0 \\
3 \\
\end{array}$ & $\begin{array}{c}930, \\
45\end{array}$ \\
\hline \multicolumn{14}{|c|}{ underground leaching solutions } \\
\hline 4 & 409 & 307 & & & 46 & & & & $\begin{array}{c}1639 \\
0\end{array}$ & 663 & & & \\
\hline
\end{tabular}

Table 2 shows the results of atomic absorption analysis of the concentration of metals in groundwater.

Table2.The results of atomic absorption analysis of the concentration of metals in groundwater

\begin{tabular}{|c|c|c|c|c|c|c|c|}
\hline \multirow[t]{2}{*}{ No. } & \multicolumn{7}{|c|}{ Analysis results, $\mathrm{mg} / \mathrm{dm} 3$} \\
\hline & Mn & $\mathbf{P b}$ & $\mathbf{C u}$ & $\mathbf{Z n}$ & Co & $\mathbf{C r}$ & $\mathbf{N i}$ \\
\hline 1 & 0,004 & $\mathbf{0 , 0 7 0}$ & 0,006 & 0,006 & $\mathbf{0 , 0 1 0}$ & $<0,001$ & $<0,001$ \\
\hline 2 & $\mathbf{0 , 0 0 3}$ & $\mathbf{0 , 0 6 0}$ & 0,006 & 0,006 & $\mathbf{0 , 0 0 3}$ & $<0,001$ & $<0,001$ \\
\hline 3 & 0,003 & 0,060 & 0,006 & $\mathbf{0 , 0 0 7}$ & $\mathbf{0 , 0 1 0}$ & $<0,001$ & $<0,001$ \\
\hline MPC * & -.- & $\mathbf{0 , 1 0 0}$ & 1,000 & 1,000 & 1,000 & 0,100 & 0,100 \\
\hline
\end{tabular}

$M P C^{*}$ - for domestic water. Handbook of an environmental expert. Tashkent 2009 Goskompriroda. 
The main method of groundwater reclamation is natural demineralization. At the same time, the main part of environmental protection measures consists in creating a network of observation wells and conducting hydrogeological monitoring until the concentration of pollutants is reduced to the MPC level or background values.

Assessment of the soil condition during underground leaching of uranium soil condition is assessed in accordance with the requirements of SanPiN No. 0079-98 (liquidation, conservation, and reprofiling of uranium mining and processing facilities) in which the upper values of the specific activity of radionuclides, the effective specific activity of alpha radiation - Aeff are established, the power of the exposure dose of gamma radiation and the $\mathrm{pH}$ of the aqueous extract in agricultural and sanitary directions.

To determine the concentration of rock-forming chemical elements in soil samples taken from sites of underground leaching of uranium, an X-ray fluorescence analysis method was carried out.

Figure 1 shows the dependence of the energy of rock-forming chemical elements on the number of pulses per minute.

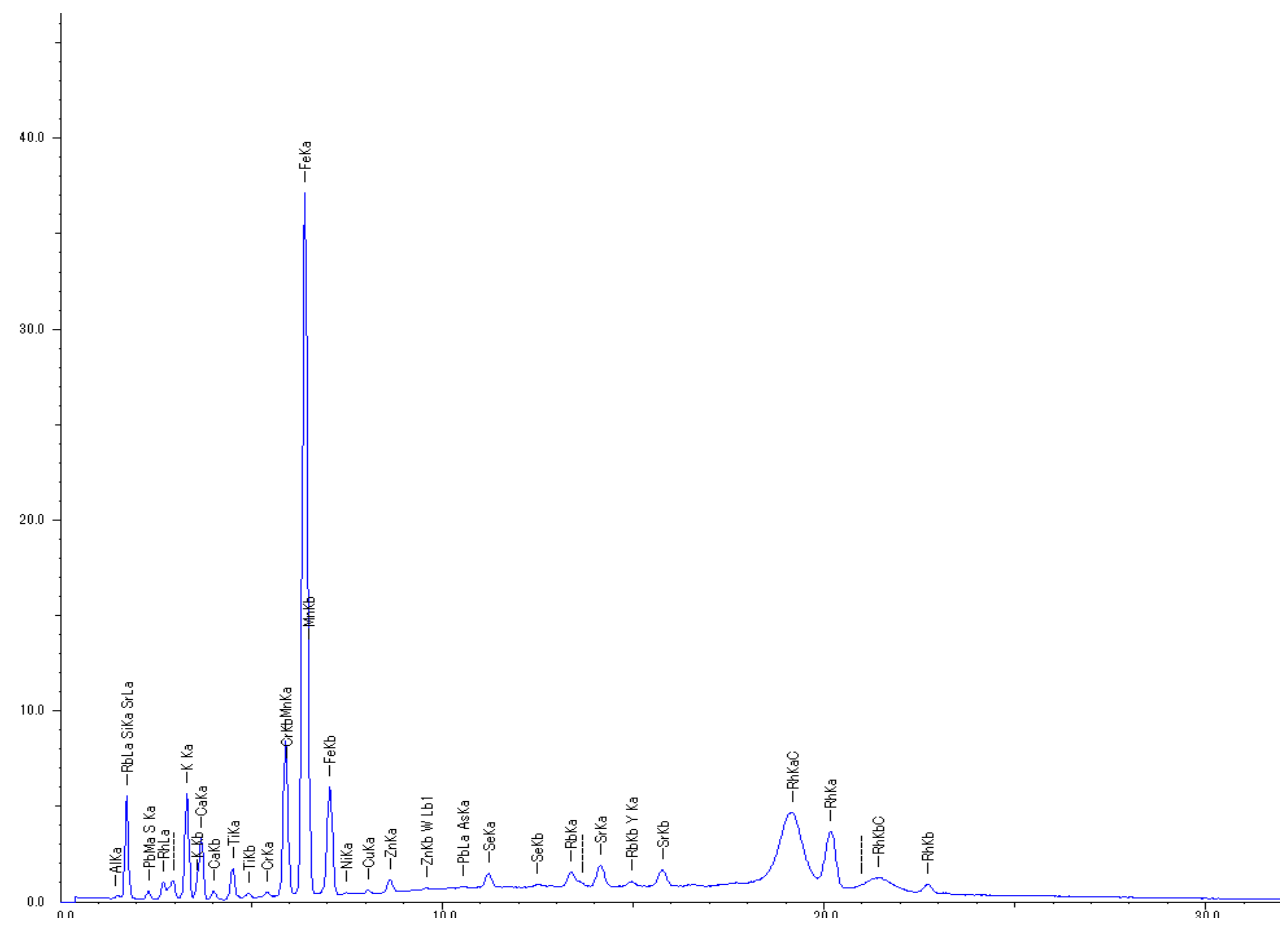

Fig1.dependence of the energy of chemical elements on the number of pulses per minute in soil samples

As can be seen from the dependence, the most important rock-forming chemical element in the soils shown in Fig. 1 is $\mathrm{SiO} 2$. The results determined by the $\mathrm{X}$-ray fluorescence method of concentration of chemical elements depicted in Fig. 1 are given in table 3.

Table3.The results of determining the concentration of rock-forming chemical elements in soil samples taken from areas of underground leaching of uranium by the X-ray fluorescence method

\begin{tabular}{|l|l|l|l|l|l|l|l|l|l|l|l|l|l|l|}
\hline Element & SiO2 & $\mathbf{K}$ & & $\mathbf{A l}$ & $\mathbf{F e}$ & $\mathbf{C a}$ & $\mathbf{M n}$ & $\mathbf{S}$ & $\mathbf{T i}$ & $\mathbf{C r}$ & $\mathbf{Z n}$ & $\mathbf{S r}$ & $\mathbf{R b}$ & $\mathbf{C u}$ \\
\hline Concentration\% & 91,7 & 2,5 & & 2,4 & 1,5 & 0,8 & 0,4 & 0,4 & 0,2 & 0,018 & 0,015 & 0,014 & 0,009 & 0,004 \\
\hline $\begin{array}{l}\text { Limit of } \\
\text { definition }\end{array}$ & & & & & & 0,001 & 0,002 & & 0,002 & 0,005 & 0,01 & - & & \\
\hline
\end{tabular}

As can be seen from the results shown in Table 3, the concentration of 13 by the chemical element in the soils does not differ much from those given in various sources. The results of this table show that it is not possible to detect radioactive elements by the X-ray fluorescence method in soil samples. In these samples, the radioactive elements were determined by the gamma spectrometric method.

The results obtained by determining the value of the specific total activity of radionuclides, the effective specific activity of alpha radiation - Aeff, the exposure dose rate of gamma radiation and the $\mathrm{pH}$ value of the aqueous extract are given in table 4. 
Table4. The results of determining the values of the specific total activity of radionuclides, the effective specific activity of alpha radiation - Aeff, the exposure dose rate of gamma radiation and the $\mathrm{pH}$ value of the aqueous extract

\begin{tabular}{|c|c|c|c|c|c|c|}
\hline \multirow[b]{2}{*}{$\begin{array}{l}\text { Sample } \\
\text { number }\end{array}$} & \multirow[b]{2}{*}{$\begin{array}{l}\text { EDR, } \\
\mu R / \text { hour }\end{array}$} & \multicolumn{4}{|c|}{ Soil specific activity } & \multirow[b]{2}{*}{$\begin{array}{l}\text { pH of the } \\
\text { aqueous extract }\end{array}$} \\
\hline & & $\begin{array}{l}K^{40} \\
\text { БК/K厂 }\end{array}$ & $\begin{array}{l}\mathrm{Ra}^{226} \\
\text { Бк/K厂 }\end{array}$ & $\begin{array}{l}T^{232} \\
\text { Бк/Кг }\end{array}$ & $\begin{array}{l}\mathbf{A}_{\text {эфф }} \\
\text { Бк/K厂 }\end{array}$ & \\
\hline \multirow{4}{*}{1} & \multirow{4}{*}{$15,6-21,7$} & 566 & 357 & 31 & 449 & 7,47 \\
\hline & & 588 & 372 & 41 & 479 & 7,26 \\
\hline & & 574 & 287 & 34 & 383 & 7,23 \\
\hline & & 548 & 259 & 38 & 358 & 7,54 \\
\hline \multirow{4}{*}{2} & \multirow{4}{*}{$16,0-42,2$} & 556 & 306 & 33 & 399 & 7,52 \\
\hline & & 565 & 741 & 40 & 844 & 7,13 \\
\hline & & 525 & 590 & 35 & 683 & 7,07 \\
\hline & & 593 & 449 & 34 & 547 & 7,26 \\
\hline \multirow{4}{*}{3} & \multirow{4}{*}{$15,8-25,3$} & 552 & 497 & 22 & 576 & 4,65 \\
\hline & & 461 & 303 & 18 & 368 & 4,16 \\
\hline & & 459 & 528 & 19 & 594 & 4,18 \\
\hline & & 507 & 238 & 26 & 318 & 7,22 \\
\hline \multirow{4}{*}{4} & \multirow{4}{*}{$46,9-66,1$} & 273 & 829 & 11 & 861 & 5,46 \\
\hline & & 105 & 1534 & 12 & 1543 & 4,25 \\
\hline & & 343 & 1348 & 15 & 1399 & 4,00 \\
\hline & & 180 & 1492 & 16 & 1516 & 3,97 \\
\hline \multirow{4}{*}{5} & \multirow{4}{*}{$50,1-67,2$} & 562 & 1249 & 19 & 1324 & 5,96 \\
\hline & & 384 & 1504 & 16 & 1560 & 3,71 \\
\hline & & 383 & 1088 & 17 & 1145 & 3,60 \\
\hline & & 323 & 1173 & 17 & 1210 & 3,73 \\
\hline
\end{tabular}

As can be seen from tab 4 of the results obtained - the EDR value varies from $15.6 \mu \mathrm{R}$ / hour to 67.2 $\mu \mathrm{R} /$ hour, the specific activity of radionuclides $-\mathrm{K}^{40}-$ varies within $(105-599) \mathrm{Bq} / \mathrm{kg}, \mathrm{Ra}^{226}$ - varies within $\left(238\right.$ - 1534) Bq / kg, $\mathrm{Th}^{232}$ - varies within $(11-41) \mathrm{Bq} / \mathrm{kg}$, the effective specific activity of alpha radiation - $\mathrm{A}_{\text {eff }}$ - varies within $(318-1560) \mathrm{Bq} / \mathrm{kg}$, and the $\mathrm{pH}$ value of the aqueous extract varies in the range of $7.54-3.60$. Here, samples 1 and 2 were taken from the soil of the underground uranium leaching sites where mini reagent (concentration of $\mathrm{H}_{2} \mathrm{SO}_{4}$ in the solution is $10-15 \mathrm{~g} / \mathrm{l}$ ) is used; uranium leaching technology; samples 3,4 and 5 were taken from the soil of the underground uranium leaching where acid (concentration $\mathrm{H}_{2} \mathrm{SO}_{4}$ in solution is 30-40 g / l) uranium leaching technology. The results show that the acidity of the soil depends on the technology used for leaching of uranium, that is, it sharply decreases from minoreagent - 7.54 to acid - 3.60. And the change in EDR values, on the contrary, increases from $15.6 \mu \mathrm{R} /$ hour to $67.2 \mu \mathrm{R} /$ hour with a change in the technology used for leaching of uranium from minireagent to acid. This fact shows that when using acid leaching of uranium, the soil is contaminated with radionuclides of the uranium decay chain to a greater extent.

Thus, on the basis of the research and the results obtained, it can be concluded that the magnitude of the influence of the process of underground leaching of uranium on the state of the soil and groundwater is estimated. It was established that the X-ray fluorescence analysis method can determine the concentration of rock-forming chemical elements in the soil, the analysis of groundwater shows that they are contaminated with radionuclides and that they have increased concentrations of chemical elements through the use of the acid method of underground leaching of uranium, the specific activity of radionuclides, the effective specific activity of alpha radiation - Aeff, the exposure dose rate of gamma radiation and the $\mathrm{pH}$ value of the aqueous extract.

\section{REFERENCES}

[1] "Radiation Safety Standards (NRB-2006) and the basic sanitary rules for ensuring radiation safety (OSPORB-2006). - Tashkent.: 2006. - 86 p.

[2] Allaberganova G.M., Turobzhonov S.M., Muzafarov A.M. Analysis of the chemical and radionuclide composition of industrial effluents of uranium production // Mountain Bulletin of Uzbekistan No. 3 (79). Navoi. 2019. -- pp. 108-109.

[3] Muzafarov A.M., Sattarov G.S., Kadirov F.M., Latyshev V.E. Methods for assessing the anthropogenic impact of tailings of industrial enterprises on the environment // Mountain Herald of Uzbekistan. 2002.№2. - pp. 85-89. 
[4] Muzafarov A.M., Sattarov G.S., Temirov B.R., Nerushchenko E.V., Buchko I.A. Comprehensive assessment of radiation dosimetric and environmental conditions in the area of activity of NMMC / Innovative technologies of the mining and metallurgical industry. Thes. doc Res. con. Navoi. October 21 st. 2011. -- pp. 213-215.

[5] Allaberganova G.M., Turobzhonov S.M., Muzafarov A.M. Methodology for the preliminary assessment of natural waters for the radioactivity of the uranium-bearing region // Mountain Herald of Uzbekistan No. 3 (78). - Navoi. 2019. -- pp. 106-108.

[6] Allaberganova G.M., Turobjonov S.M., Muzafarov A.M., Jurakulov A.R., Urunov I.A., Abdiraxmonov U.Sh. Method for Conducting of Uranium Isotopic Analysis in Various Natural Waters of UraniumBearing Regions of Uzbekistan // International Journal of Academic Multidisciplinary Research (IJAMR). Vol. 3 Issue: 10 October 2019 .-- Washington DC, USA. - pp. 52-55.

[7] Allaberganova G.M., Muzafarov A.M., Mustafoev M.A. Methodology for conducting isotopic analysis of uranium in various natural waters of uranium-bearing regions of Uzbekistan. Collection of articles of the international scientific and practical conference / Ecological, industrial and energy safety-2019. Sevastopol. Russia. September 23-26, 2019. pp. 1104-1107.

[8] Allaberganova G.M., Muzafarov A.M., Sattarov G.S., Zhurakulov A.R. Radiometric assessment of the radiation situation in the industrial and nearby areas of uranium mining enterprises. Abstracts of the 9th International Conference / Nuclear and Radiation Physics. - Almaty. Kazakhstan. 2013. pp. 222-223.

Citation: Allaberganova G.M., et.al, (2019)" Assessment of the Influence of the Process of Underground Uranium Leaching on Soil and Groundwater", Southeast Cameroon, International Journal of Mining Science (IJMS), 5(4), pp.30-34, DOI: http://dx.doi.org/10.20431/2454-9460.0504003

Copyright: (C) 2019 Authors. This is an open-access article distributed under the terms of the Creative Commons Attribution License, which permits unrestricted use, distribution, and reproduction in any medium, provided the original author and source are credited 